\title{
Geology
}

\section{Not all supercontinents are created equal: Gondwana-Rodinia case study}

\author{
Christopher J. Spencer, Chris Hawkesworth, Peter A. Cawood and Bruno Dhuime
}

Geology published online 6 June 2013; doi: $10.1130 / G 34520.1$

\section{Email alerting services}

Subscribe

Permission request click www.gsapubs.org/cgi/alerts to receive free e-mail alerts when new articles cite this article

click www.gsapubs.org/subscriptions/ to subscribe to Geology

click http://www.geosociety.org/pubs/copyrt.htm\#gsa to contact GSA

Copyright not claimed on content prepared wholly by U.S. government employees within scope of their employment. Individual scientists are hereby granted permission, without fees or further requests to GSA, to use a single figure, a single table, and/or a brief paragraph of text in subsequent works and to make unlimited copies of items in GSA's journals for noncommercial use in classrooms to further education and science. This file may not be posted to any Web site, but authors may post the abstracts only of their articles on their own or their organization's Web site providing the posting includes a reference to the article's full citation. GSA provides this and other forums for the presentation of diverse opinions and positions by scientists worldwide, regardless of their race, citizenship, gender, religion, or political viewpoint. Opinions presented in this publication do not reflect official positions of the Society.

\section{Notes}

Advance online articles have been peer reviewed and accepted for publication but have not yet appeared in the paper journal (edited, typeset versions may be posted when available prior to final publication). Advance online articles are citable and establish publication priority; they are indexed by GeoRef from initial publication. Citations to Advance online articles must include the digital object identifier (DOIs) and date of initial publication.

(C) Geological Society of America

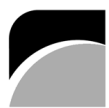

THE GEOLOGICAL SOCIETY OF AMERICA 


\title{
Not all supercontinents are created equal: Gondwana-Rodinia
} case study

\author{
Christopher J. Spencer ${ }^{1}$, Chris Hawkesworth ${ }^{1}$, Peter A. Cawood ${ }^{1}$, and Bruno Dhuime ${ }^{1,2}$ \\ ${ }^{1}$ Department of Earth and Environmental Sciences, University of St. Andrews, North Street, St. Andrews KY16 9AL, UK \\ ${ }^{2}$ Department of Earth Sciences, University of Bristol, Wills Memorial Building, Queens Road, Bristol BS8 1RJ, UK
}

\section{ABSTRACT}

The geologic records associated with the formation of the supercontinents Rodinia and Gondwana have markedly different seawater $\mathrm{Sr}$ and zircon Hf isotopic signatures. Rodinia-related (GrenvilleSveconorwegian-Sunsas) orogens display significantly less enriched crustal signatures than Gondwana-related (Pan-African) orogens. Seawater $\mathrm{Sr}$ isotope ratios also exhibit a more pronounced crustal signal during the span of the Gondwana supercontinent than at the time of Rodinia. Such isotopic differences are attributed to the age and nature of the continental margins involved in the collisional assembly, and specifically to the depleted mantle model ages, and hence the isotope ratios of the material weathered into the oceans. In our preferred model the isotopic signatures of Rodinia-suturing orogens reflect the closure of ocean basins with dual subduction zones verging in opposite directions, analogous to the modern Pacific basin. This would have resulted in the juxtaposition of juvenile continental and island arc terrains on both margins of the colliding plates, thus further reworking juvenile crust. Conversely, the assembly of Gondwana was accomplished primarily via a number of single-sided subduction zones that involved greater reworking of ancient cratonic lithologies within the collisional sutures. The proposed geodynamic models of the assembly of Rodinia and Gondwana provide a connection between the geodynamic configuration of supercontinent assembly and its resulting isotopic signature.

\section{INTRODUCTION}

Secular trends of geologic features such as U-Pb detrital zircon ages, abundance of passive margins, and $\mathrm{Sr}$ isotopes in seawater vary with the cycle of assembly and dispersal of supercontinents (Fig. 1; Hawkesworth et al., 2010; Bradley, 2011; Cawood et al., 2013). The running average of epsilon $(\varepsilon) \mathrm{Hf}$ in zircon has similar secular trends with peaks and troughs of positive and negative values (Fig. 1; e.g., Belousova

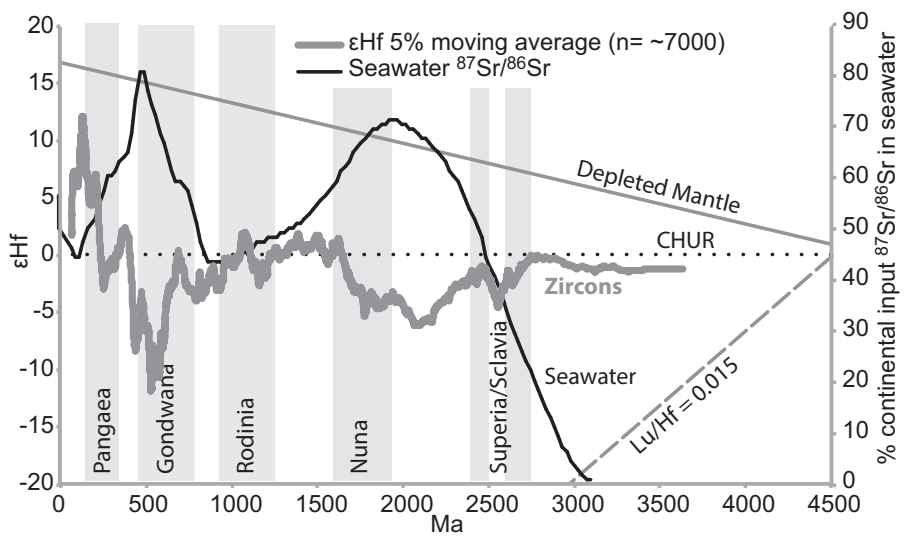

Figure 1. Normalized seawater ${ }^{87} \mathrm{Sr} /{ }^{86} \mathrm{Sr}$ curve (Shields, 2007) plotted with $5 \%$ running average of initial zircon $8 \mathrm{Hf}$ (i.e., $5 \%$ of total number, $\mathrm{n}$, in database is used for period of running average) from global database of modern and recent river sediments (see Dhuime et al., 2012, for references). Time periods of Grenville and Pan-African orogenic events (Bradley, 2011) are outlined (CHUR-chondrite uniform reservoir). et al., 2010; Roberts, 2012; Cawood et al., 2013). Specifically, the running average of $\varepsilon \mathrm{Hf}$ analyses from a worldwide database of $\sim 7000$ $\mathrm{U}-\mathrm{Pb}$ and $\mathrm{Hf}$ analyses of zircons from Phanerozoic sediments (from Dhuime et al., 2012) shows the most negative trough of -12 at $550 \mathrm{Ma}$ (Fig. 1), corresponding to the timing of the Gondwana-forming orogenies. These strongly negative values associated with Gondwana assembly contrast with those at the time of the Rodinia-forming orogenies (1250$980 \mathrm{Ma})$, when the $\varepsilon \mathrm{Hf}$ running mean remains near the chondritic uniform reservoir (Fig. 1).

We argue that the $\mathrm{Sr}$ and $\mathrm{Hf}$ isotopic characteristics of material formed during the assembly of supercontinents (specifically Rodinia and Gondwana), and consequently the Sr isotope ratios of seawater, are consequences of the age and isotope composition of the margins associated with the assembly of each supercontinent. We relate these isotopic features to differing models of supercontinent assembly.

\section{RODINIA AND GONDWANA CONTINENTAL MARGINS}

The ages of preserved continental margins involved in the assembly of Rodinia and Gondwana differ significantly in age and isotopic character. Relatively young, isotopically juvenile rock units dominate the continental margins incorporated into Rodinia, whereas the Gondwanan margins are significantly older and more evolved. Prior to the Rodinia-forming orogenies, the early Mesoproterozoic crust of the 1.5-1.3 Ga Granite-Rhyolite (USA), 1.51-1.45 Ga Pinwarian (Canada), 1.56-1.3 Ga Rondonian (Brazil), and 1.52-1.48 Ga Idefjorden, Bamble, and Telemark (Norway) provinces (Whitmeyer and Karlstrom, 2007; Bettencourt et al., 2010; Bingen et al., 2008) dominated the colliding margins of Laurentia, Amazonia, and Baltica. The rocks on these margins were $<400$ m.y. old at the time of collisional assembly. Other end-Mesoproterozoic orogenic events are also found in Australia, Antarctica, India, and north China; however, the assembly of these blocks resulted in geographically restricted episodes of magmatism (e.g., Kröner et al., 2003; Collins and Pisarevsky, 2005; Cawood and Kosch, 2008; Zhao and Cawood, 2012) (Fig. 2B). In contrast, Archean and Paleoproterozoic crust dominates the continental margins associated with the assembly of Gondwana. The Damara-Zambezi belt juxtaposes the northern Archean-Paleoproterozoic margins of the Kalahari craton and Rayner-Rauer complex with the southern Archean margins of the Congo and Dharwar cratons (Gray et al., 2008, and references therein; de Waele et al., 2008). The Dahomeyide, Pinjarra, and Brasiliano collisional orogens share similar relationships (e.g., Cawood, 2005; Rapela et al., 2011). These margins were significantly older at the onset of the amalgamation of Gondwana than those involved in the formation of Rodinia.

Using geologic maps and ArcGIS the present-day lengths of the margins were measured for the Rodinia- and Gondwana-forming orogens and the adjacent geologic provinces. This indicates that $63 \%$ of the Grenville-Sunsas-Sveconorwegian orogenies were juxtaposed with $1.3-1.5 \mathrm{Ga}$ crust, the remaining comprising ca. 1.7-1.9 Ga crust (e.g., Labradorian and Yavapai provinces) (Fig. 2B). This is in stark contrast to the Gondwana-forming (Pan-African) orogenies, in which 58\% of the margins involved are adjacent to Archean cratons and the remaining are comprised of Neoproterozoic and Mesoproterozoic crust and minor Paleoproterozoic crust (Fig. 2A).

Assuming that the present distribution of exposed rock units is representative of the relations at the time of syncollisional erosion, we 


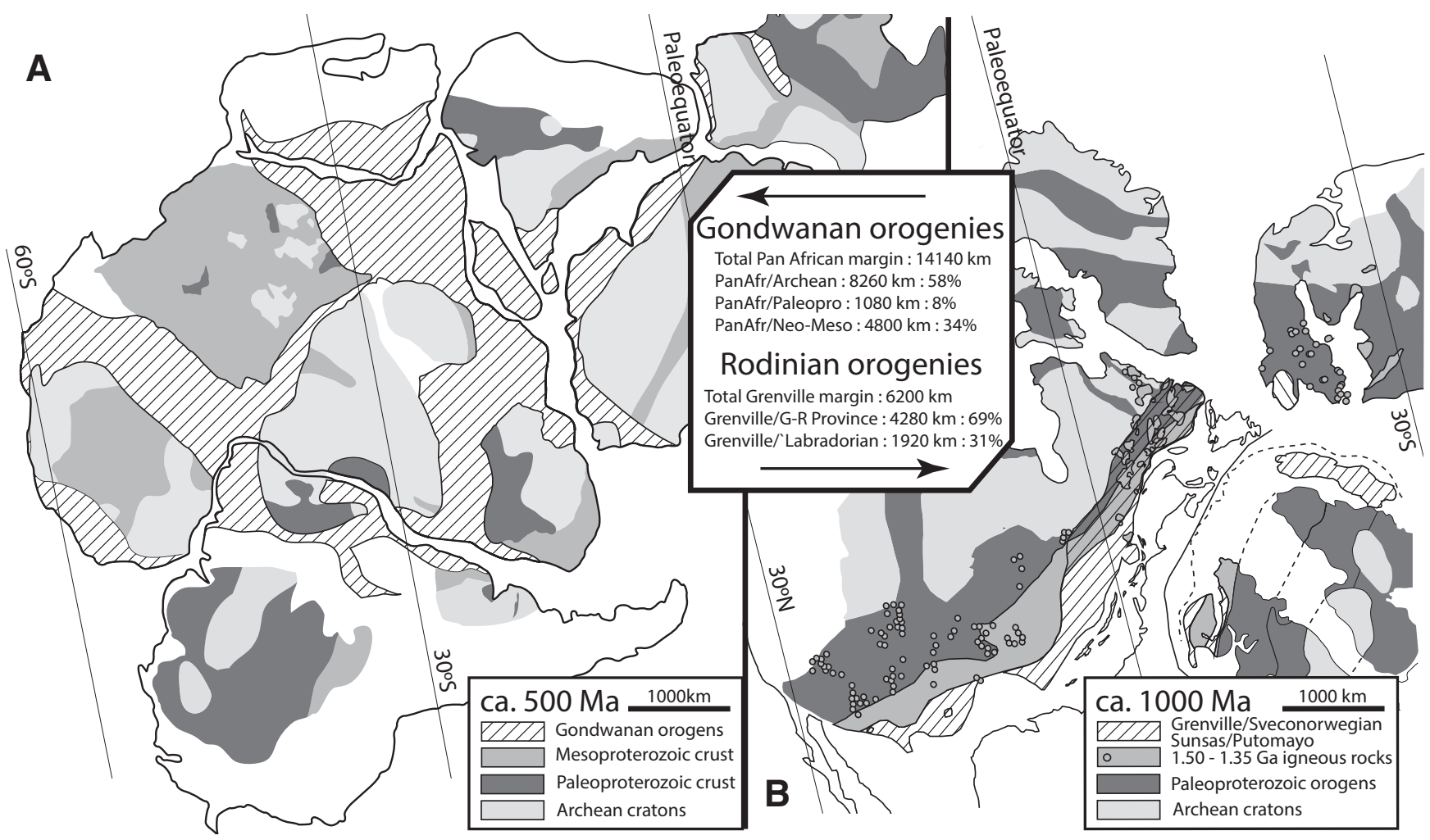

Figure 2. A: Map of Gondwana (ca. $500 \mathrm{Ma}$ ) showing extent of Gondwana-forming orogenies and distribution of Precambrian provinces (modified from Li et al., 2008; Cawood and Buchan, 2007; Torsvik and Cocks, 2009, and references therein). B: Map of Laurentia (ca. 1.3 Ga), with Paleozoic and younger geology omitted, showing extent of Rodinia-forming orogenies (modified from Tohver et al., 2002; Cawood and Buchan, 2007; Jacobs et al., 2008). PanAfr-Pan African; Paleopro-Paleoproterozoic; Meso-Mesoproterozoic; Neo-Neoproterozoic; G-R-Granite-Rhyolite.

compared the relative proportions of juvenile versus evolved crust associated with orogenesis during assembly of Rodinia and Gondwana. The compiled $\mathrm{U}-\mathrm{Pb}$ and $\mathrm{Hf}$ analyses from Phanerozoic sediments (from Dhuime et al., 2012) were used to evaluate initial Hf isotope ratios in zircon and Hf depleted mantle model ages for zircons that crystallized in the periods associated with the assemblies of Gondwana and Rodinia in the Pan-African and Grenville orogenies, respectively.

Zircons with U-Pb crystallization ages of 520-650 Ma were selected to represent the isotope compositions of the rocks associated with the formation of Gondwana, and those with ages of 980-1250 Ma represent the assembly of Rodinia (Cawood and Buchan, 2007; Bradley, 2011). Depleted mantle model ages were then normalized to ages of 900 and $480 \mathrm{Ma}$, which broadly represent the end of the Rodinia- and Gondwanaforming orogenies, respectively (i.e., 480 and 900 Ma were subtracted from the present-day depleted mantle model ages of zircons that crystallized in the time periods identified, using an average crustal $\mathrm{Lu} / \mathrm{Hf}=0.15$ ). Integration of probability density plots highlights that Rodinia-forming orogenies incorporate significantly more material with relatively young model ages, whereas Gondwana-forming orogens have a greater proportion of relative old model ages (Fig. 3).

The average depleted mantle model $\mathrm{Hf}$ ages from the Gondwanaand Rodinia-forming orogenies were in turn used to calculate the bulk $\mathrm{Sr}$ isotopic composition of the eroded margins at $900 \mathrm{Ma}$ for Rodinia and $480 \mathrm{Ma}$ for Gondwana assuming an average upper crustal $\mathrm{Rb} / \mathrm{Sr}$ ratio of 0.256 (Rudnick and Gao, 2003). The $\mathrm{Sr}$ isotope ratio of seawater is $\sim 0.7053$ at $900 \mathrm{Ma}$ and $\sim 0.7082$ at $480 \mathrm{Ma}$ (from Shields, 2007), and the calculated average $\mathrm{Sr}$ isotope ratios of the active margins at those times were 0.709 and 0.711 , respectively. Thus the $\mathrm{Sr}$ isotope ratio of seawater increased by 0.0029 between $900 \mathrm{Ma}$ and $480 \mathrm{Ma}$, and the runoff from the active margins increased by 0.0019 . Assuming that the $\mathrm{Sr}$ abundances in the fluxes from the mantle and crustal end members are similar to those of the present day, much of the difference between the Sr isotope signals for the Rodinia- and Gondwana-forming orogenies can therefore be attributed to the differences in the ages of the preexisting rocks reworked along those margins, and the rest may largely reflect the Sr isotope ratios of continental runoff from areas not involved in these two orogenic systems.

The different zircon Hf and seawater Sr isotope signatures of the Grenville and Pan-African orogenic systems is readily explained by contrasting geodynamic scenarios. The assembly of Rodinia (ca. 1250$1140 \mathrm{Ma}$ ) was primarily accomplished through dual opposing subduction zones beneath the Kalahari-Amazonia on one side (Ibanez-Mejia et al., 2011, and references therein; Jacobs et al., 2008) and Laurentia-Baltica on the other (Cawood et al., 2007; Rivers and Corrigan, 2000, and references therein; Bingen et al., 2008) (Fig. 4). This dual-sided subduction system juxtaposed juvenile continental arcs on the colliding continental margins. Several previously accreted island arc terranes are also found throughout the Grenville and related orogens (Rivers and Corrigan, 2000; Bingen et al., 2008), adding to the juvenile component of the continental margins. Compiled zircon Hf isotopes from Grenville-derived sedimentary rocks in Laurentia and Baltica (Fig. DR1 in the GSA Data Repository ${ }^{1}$ ) show an increasingly juvenile signature with time just prior to the collisional assembly of Amazonia, Laurentia, and Baltica (i.e., the ca. 1.5-1.3 Ga Granite-Rhyolite, Pinwarian, Labradorian, and Gothian provinces),

${ }^{1}$ GSA Data Repository item 2013219, compiled zircon Hf isotopes from sedimentary rocks derived from the Grenville/Sveconorwegian and Pan-African orogenies (sensu stricto), is available online at www.geosociety.org/pubs/ft2013.htm, or on request from editing@geosociety.org or Documents Secretary, GSA, P.O. Box 9140, Boulder, CO 80301, USA 
Hf Depleted Mantle Model Ages from orogen specific detrital zircons

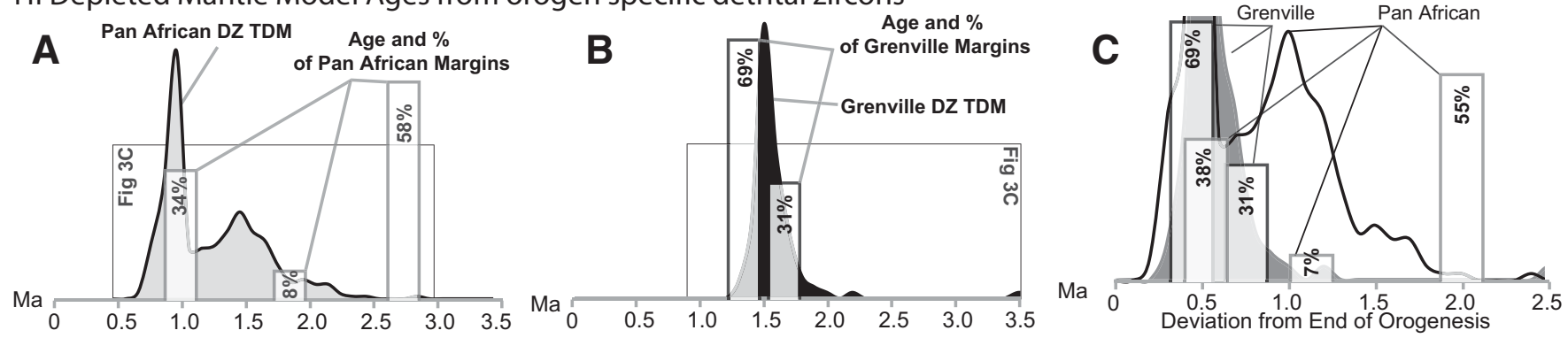

Figure 3. Relative probability of zircon Hf-depleted mantle model ages (TDM) of Grenville and Pan-African orogenies and percentage of pre-1.0 Ga and post-1.0 Ga analyses (shaded probability density plot). Percentage and age of continental margins involved in assembly of Rodinia and Gondwana are superimposed on TDM distributions (spaced histogram). Ages of margins are generalized average not representing exact span of time. A: Pan-African. B: Grenville. C: Closeup of left side of TDM distributions. Ages of margins and TDM ages are normalized to end of respective collisional orogenies.

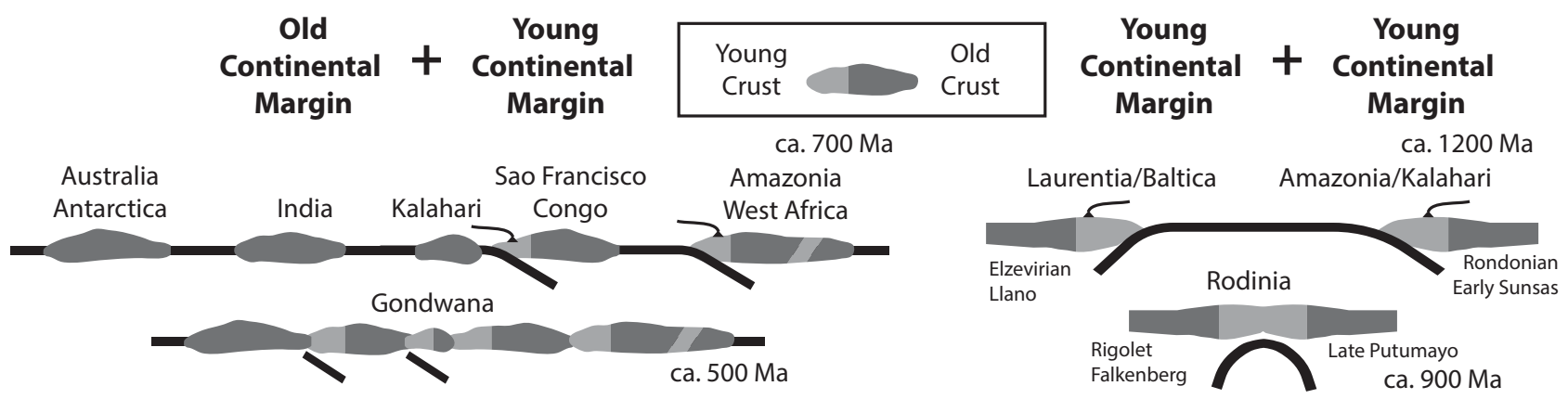

Figure 4. Contrasting supercontinent geodynamic models of Rodinia and Gondwana (modified from the modern circum-Pacific and Eurasian orogenic models of Collins et al., 2011).

consistent with a dual-opposing subduction model, and analogous to the modern Pacific (Fig. 4; see also Collins et al., 2011). Following the initial stages of collision (ca. $1.25 \mathrm{Ga}$ ), zircon Hf isotopes became increasingly isotopically enriched with a greater degree of crustal reworking (Fig. DR1).

The assembly of Gondwana was primarily accomplished through collision between the Amazonian-West African, Sao Francisco-Congo, Kalahari, India, and Australia-Antarctica cratons between 650 and $520 \mathrm{Ma}$ (Collins and Pisarevsky, 2005; Cawood and Buchan, 2007) (Fig. 4). In contrast to the assembly of Rodinia, the isotopic data associated with the assembly of Gondwana require the incorporation of greater proportions of older crustal material (Avigad et al., 2012). We infer that the assembly of Gondwana was dominated by single-sided subduction, which allowed for the juxtaposition of juvenile continental arcs with passive margins (see also Meert, 2003; Gray et al., 2008). Although the Pan-African and other orogens associated with the assembly of Gondwana have a significant juvenile component in some areas (e.g., accreted island arcs and ophiolites of the Arabian-Nubian shield) (Stern, 2002; Johnson et al., 2011), Hf isotopic signatures indicate that an evolved continental signature dominated the orogenic system (Fig. 4). This is similar to the long-lived unidirectional subduction systems of Eurasia (Fig. DR1; see also Collins et al., 2011).

The observed isotopic patterns associated with the assembly of Gondwana and Rodinia reflect the ages of the contemporaneous continental margins and different styles of subduction and subsequent collision. These patterns can aid in the discrimination of various geodynamic styles of continental collision (e.g., single versus dual-sided assembly; Collins et al., 2011). Further work is needed along the margins of the other ancient supercontinents to assess the geodynamic configuration of supercontinent assembly and associated isotopic characteristics.

\section{ACKNOWLEDGMENTS}

We thank the University of St. Andrews and Natural Environment Research Council for funding support. Comments and discussion from Kent Condie, Alan Collins, and Ian Fitzsimmons are gratefully acknowledged; the manuscript benefited greatly from their input. We also thank Carl Hoiland, Jen Chambers, and Tony Prave for stimulating conversations and helpful reviews.

\section{REFERENCES CITED}

Avigad, D., Gerdes, A., Morag, N., and Bechstädt, T., 2012, Coupled U-Pb-Hf of detrital zircons of Cambrian sandstones from Morocco and Sardinia: Implications for provenance and Precambrian crustal evolution of North Africa: Gondwana Research, v. 21, p. 690-703, doi: 10.1016/j.gr.2011.06.005.

Belousova, E.A., Kostitsyn, Y.A., Griffin, W.L., Begg, G.C., O'Reilly, S.Y., and Pearson, N.J., 2010, The growth of the continental crust: Constraints from zircon Hf-isotope data: Lithos, v. 119, p. 457-466, doi:10.1016/j.lithos.2010.07.024.

Bettencourt, J.S., Leite, W.B., Ruiz, A.S., Matos, R., Payolla, B.L., and Tosdal, R.M., 2010, The Rondonian-San Ignacio Province in the SW Amazonian Craton: An overview: Journal of South American Earth Sciences, v. 29, p. 28-46, doi:10.1016/j.jsames.2009.08.006.

Bingen, B., Nordgulen, O., and Viola, G., 2008, A four-phase model for the Sveconorwegian orogeny, SW Scandinavia: Norwegian Journal of Geology, v. 88, p. $43-72$.

Bradley, D.C., 2011, Secular trends in the geologic record and the supercontinent cycle: Earth-Science Reviews, v. 108, p. 16-33, doi:10.1016/j.earscirev.2011 .05 .003 .

Cawood, P.A., 2005, Terra Australis Orogen: Rodinia breakup and development of the Pacific and Iapetus margins of Gondwana during the Neoproterozoic and Paleozoic: Earth-Science Reviews, v. 69, p. 249-279, doi:10.1016/j.earscirev .2004.09.001. 


\section{Geology, published online on 6 June 2013 as doi:10.1130/G34520.1}

Cawood, P.A., and Buchan, C., 2007, Linking accretionary orogenesis with supercontinent assembly: Earth-Science Reviews, v. 82, p. 217-256, doi:10.1016/j .earscirev.2007.03.003.

Cawood, P.A., and Korsch, R.J., 2008, Assembling Australia: Proterozoic building of a continent: Precambrian Research, v. 166, p. 1-35, doi:10.1016/j.precamres .2008.08.006.

Cawood, P.A., Nemchin, A.A., Strachan, R., Prave, T., and Krabbendam, M., 2007, Sedimentary basin and detrital zircon record along East Laurentia and Baltica during assembly and breakup of Rodinia: Journal of the Geological Society of London, v. 164, doi:10.1144/0016-76492006-115.

Cawood, P.A., Hawkesworth, C.J., and Dhuime, B., 2013, The continental record and the generation of continental crust: Geological Society of America Bulletin, v. 125, p. 14-32, doi:10.1130/B30722.1.

Collins, A.S., and Pisarevsky, S.A., 2005, Amalgamating eastern Gondwana: The evolution of the Circum-Indian orogens: Earth-Science Reviews, v. 71, p. 229-270, doi:10.1016/j.earscirev.2005.02.004.

Collins, W.J., Belousova, E.A., Kemp, A.I.S., and Murphy, J.B., 2011, Two contrasting Phanerozoic orogenic systems revealed by hafnium isotope data: Nature Geoscience, v. 4, p. 333-337, doi:10.1038/ngeo1127.

de Waele, B., Johnson, S.P., and Pisarevsky, S.A., 2008, Palaeoproterozoic to Neoproterozoic growth and evolution of the eastern Congo Craton: Its role in the Rodinia puzzle: Precambrian Research, v. 160, p. 127-141, doi:10.1016/j.precamres.2007.04.020.

Dhuime, B., Hawkesworth, C.J., Cawood, P.A., and Storey, C.D., 2012, A change in the geodynamics of continental growth 3 billion years ago: Science, v. 335 , no. 6074 , p. $1334-1336$, doi:10.1126/science. 1216066 .

Gray, D.R., Foster, D.A., Meert, J.G., Goscombe, B.D., Armstrong, R., Trouw, R.J., and Passchier, C.W., 2008, A Damara orogen perspective on the assembly of southwestern Gondwana, in Pankhurst, R.J., et al., eds., West Gondwana: PreCenozoic correlations across the South Atlantic region: Geological Society of London Special Publication 294, p. 257-278, doi:10.1144/SP294.14.

Hawkesworth, C.J., Dhuime, B., Pietranik, A.B., Cawood, P.A., Kemp, A.I.S., and Storey, C.D., 2010, The generation and evolution of the continental crust: Geological Society of London Journal, v. 167, p. 229-248, doi:10.1144/0016 -76492009-072.

Ibanez-Mejia, M., Ruiz, J., Valencia, V.A., Cardona, A., Gehrels, G.E., and Mora, A.R., 2011, The Putumayo Orogen of Amazonia and its implications for Rodinia reconstructions: New U-Pb geochronological insights into the Proterozoic tectonic evolution of northwestern South America: Precambrian Research, v. 191, p. 58-77, doi:10.1016/j.precamres.2011.09.005.

Jacobs, J., Pisarevsky, S., Thomas, R.J., and Becker, T., 2008, The Kalahari Craton during the assembly and dispersal of Rodinia: Precambrian Research, v. 160, p. 142-158, doi:10.1016/j.precamres.2007.04.022.

Johnson, P.R., Andresen, A., Collins, A.S., Fowler, A.R., Fritz, H., Ghebreab, W., Kusky, T., and Stern, R.J., 2011, Late Cryogenian-Ediacaran history of the Arabian-Nubian Shield: A review of depositional, plutonic, structural, and tectonic events in the closing stages of the northern East African Orogen: Journal of African Earth Sciences, v. 61, p. 167-232, doi:10.1016/j .jafrearsci.2011.07.003.
Kröner, A., Kehelpannala, K.V., and Hegner, E., 2003, Ca. 750-1100 Ma magmatic events and Grenville-age deformation in Sri Lanka: Relevance for Rodinia supercontinent formation and dispersal, and Gondwana amalgamation: Journal of Asian Earth Sciences, v. 22, p. 279-300, doi:10.1016 /S1367-9120(03)00060-9.

Li, Z.X., and 13 others, 2008, Assembly, configuration, and break-up history of Rodinia: A synthesis: Precambrian Research, v. 160, p. 179-210, doi:10.1016 /j.precamres.2007.04.021.

Meert, J.G., 2003, A synopsis of events related to the assembly of eastern Gondwana: Tectonophysics, v. 362, p. 1-40, doi:10.1016/S0040-1951(02)00629-7.

Rapela, C.W., Fanning, C.M., Casquet, C., Pankhurst, R.J., Spalletti, L., Poiré, D., and Baldo, E.G., 2011, The Rio de la Plata craton and the adjoining Pan-African/Brasiliano terranes: Their origins and incorporation into southwest Gondwana: Gondwana Research, v. 20, p. 673-690, doi:10.1016/j.gr .2011.05.001.

Rivers, T., and Corrigan, D., 2000, Convergent margin on southeastern Laurentia during the Mesoproterozoic: Tectonic implications: Canadian Journal of Earth Sciences, v. 37, p. 359-383, doi:10.1139/e99-067.

Roberts, N.M.W., 2012, Increased loss of continental crust during supercontinent amalgamation: Gondwana Research, v. 21, p. 994-1000, doi:10.1016/j.gr .2011.08.001.

Rudnick, R., and Gao, S., 2003, Composition of the continental crust, in Rudnick, R.L., ed., The Crust: Treatise on Geochemistry, Volume 3: Oxford, UK, Elsevier-Pergamon, p. 1-64.

Shields, G.A., 2007, A normalised seawater strontium isotope curve: Possible implications for Neoproterozoic-Cambrian weathering rates and the further oxygenation of the Earth: eEarth, v. 2, p. 35-42, doi:10.5194/ee-2-35-2007.

Stern, R.J., 2002, Crustal evolution in the East African Orogen: A neodymium isotopic perspective: Journal of African Earth Sciences, v. 34, p. 109-117, doi:10.1016/S0899-5362(02)00012-X.

Tohver, E., Van der Pluijm, B.A., Van der Voo, R., Rizzotto, G., and Scandolara, J.E., 2002, Paleogeography of the Amazon craton at $1.2 \mathrm{Ga}$ : Early Grenvillian collision with the Llano segment of Laurentia: Earth and Planetary Science Letters, v. 199, p. 185-200, doi:10.1016/S0012-821X(02)00561-7.

Torsvik, T.H., and Cocks, L.R.M., 2009, The lower Palaeozoic palaeogeographical evolution of the northeastern and eastern peri-Gondwanan margin from Turkey to New Zealand, in Bassett, M.G., ed., Early Palaeozoic peri-Gondwana terranes: New insights from tectonics and biogeography: Geological Society of London Special Publication 325, p. 3-21, doi:10.1144/SP325.2.

Whitmeyer, S., and Karlstrom, K., 2007, Tectonic model for the Proterozoic growth of North America: Geosphere, v. 3, p. 220-259, doi:10.1130/GES00055.1.

Zhao, G., and Cawood, P.A., 2012, Precambrian geology of China: Precambrian Research, v. 222-223, p. 13-54, doi:10.1016/j.precamres.2012.09.017.

Manuscript received 14 November 2012

Manuscript accepted 27 February 2013

Printed in USA 